\title{
GRAVE MONUMENTS FROM JIYEH (PORPHYREON) AND THE SEPULCHRAL ART OF SIDON'S CHORA
}

\begin{abstract}
Hellenistic steles and Roman cippi and sarcophagi discovered in the course of salvage excavations in Jiyeh (ancient Porphyreon) opened the way to the discussion of the artistic culture of Sidon and the northern part of its hinterland. The form and decoration of these grave monuments find no parallels outside the Sidonian cemeteries, pointing to very strong artistic ties between the metropolis and the villages in its chora. Compared to the output of other Syro-Palestinian sculptural centers, the products from Sidonian territory demonstrate exceptional originality, foremost in the choice of decorative motifs, but also concerning the stone material: local sandstone conglomerate and limestone. The steles, cippi and sarcophagi from Jiyeh enable us to date more precisely the locality's northern necropolis that functioned, in the light of the presented evidence, from the Hellenistic to the early Byzantine period. Moreover, the dating of the monuments leads to the assumption that the early phase of the cemetery coincided with the operation of nearby pottery workshops.
\end{abstract}

Salvage excavations in Jiyeh in 2004-05 uncovered a necropolis with 27 tombs representing at least three different types, that is, chamber tombs, loculi tombs and simple rock-hewn pit graves. ${ }^{1}$ The construction of a holiday resort in this area resulted in the destruction of most of the sepulchers, but not before a full documentation in drawing was completed and the finds collected. ${ }^{2}$ The dating of the burial ground is still pending in view of the extended process of research on the finds, but it is evident that the necro- polis served a local settlement identified with ancient Porphyreon. ${ }^{3}$ While the archaeological data from excavations in the southern part of the settlement has set a date for its occupation from at least Iron Age II through the 7th century AD, the Persian, Hellenistic, early Roman and early Byzantine

1 On the excavations in this part of the site, see WICENCIAK et al. 2003: 129-130; DOMŻALSKI et al. 2005.

2 My heartfelt thanks go to Myriam Ziade for the opportunity to see the monuments from Sidonian necropolises, held in the lapidary of the Department of Antiquities of the District of Sidon, next to the College Excavation Site; Mahmoud El Tayeb for permission to use photographs from the Barja necropolis which he is excavating; Marek Puszkarski and Magdalena Makowska for drawing the steles and sarcophagi from Jiyeh; and Tomasz Waliszewski, head of the Polish-Lebanese archaeological mission exploring Jiyeh, for making available the documentation of the salvage excavations carried out in the necropolis.

3 LIPIŃSKI 2004: 20-21, 289. periods are best represented in the material. ${ }^{4}$ In 2012 and 2013 the author studied and documented steles, cippi and sarcophagi from the necropolis. The present article refers primarily to these finds that are still at the site, ${ }^{5}$ aiming foremost at the provisional characteristic of them and their place in a broader cultural context. A full catalog will be published as part of a monograph on the Polish-Lebanese excavations in Jiyeh which is currently under preparation.

\section{STELES}

Three steles were still seen at the site. They were made of sandstone conglomerate that is available in the region (the term used locally is ramleh). The steles are all damaged, chiefly due to modern building development in this area. A plaster ground layer for painted decoration was observed on the front of all the monuments, but the surviving traces of painting were insufficient for the iconography of the decoration to be identified. For the same reason it is impossible to say whether there were any graffiti on the steles.

\footnotetext{
4 Cf. WALISZEWSKI et al. 2006.

5 The finds inventory from the excavations contains more steles, cippi and sarcophagi from the necropolis than those presented in this article, but not all of the monuments could be identified at the site.
} 

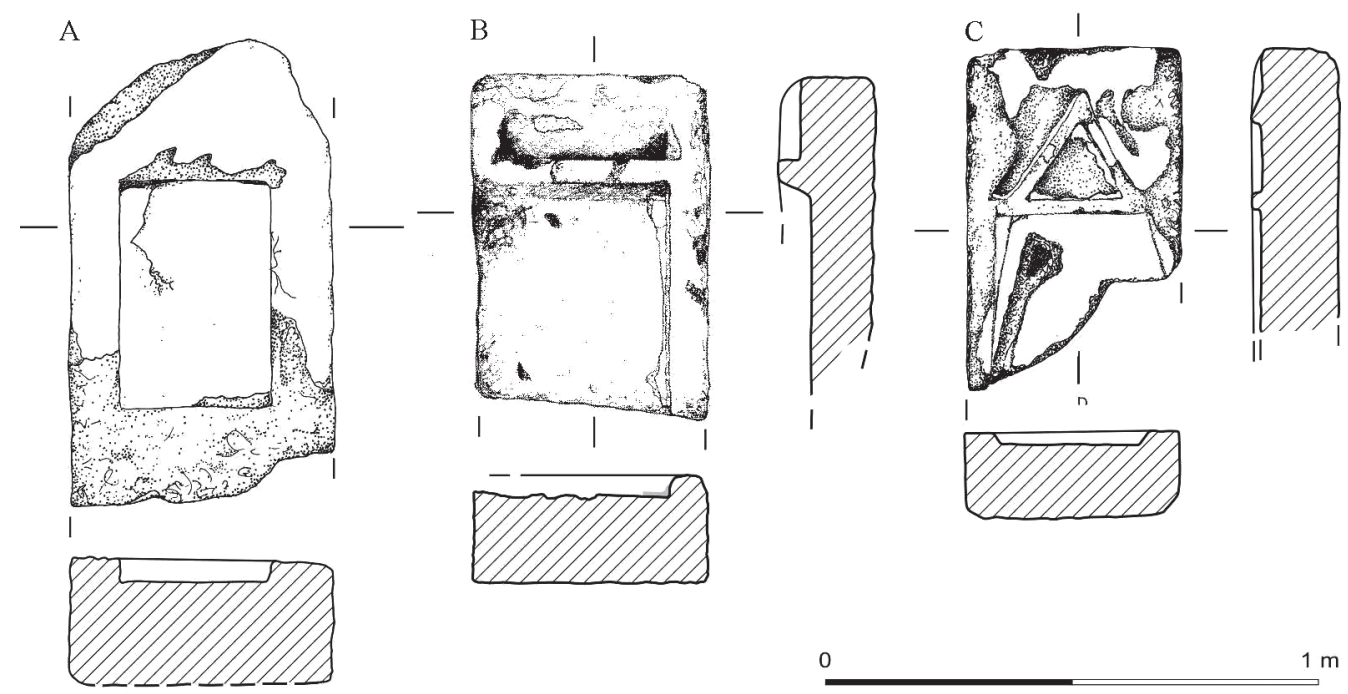

0

$1 \mathrm{~m}$

Fig. 1. Steles from Jiyeh. A - JY 17-12-S-MR; B - JY 1-13-S-MR; C - JY 21-12-S-MR (drawing M. Makowska)
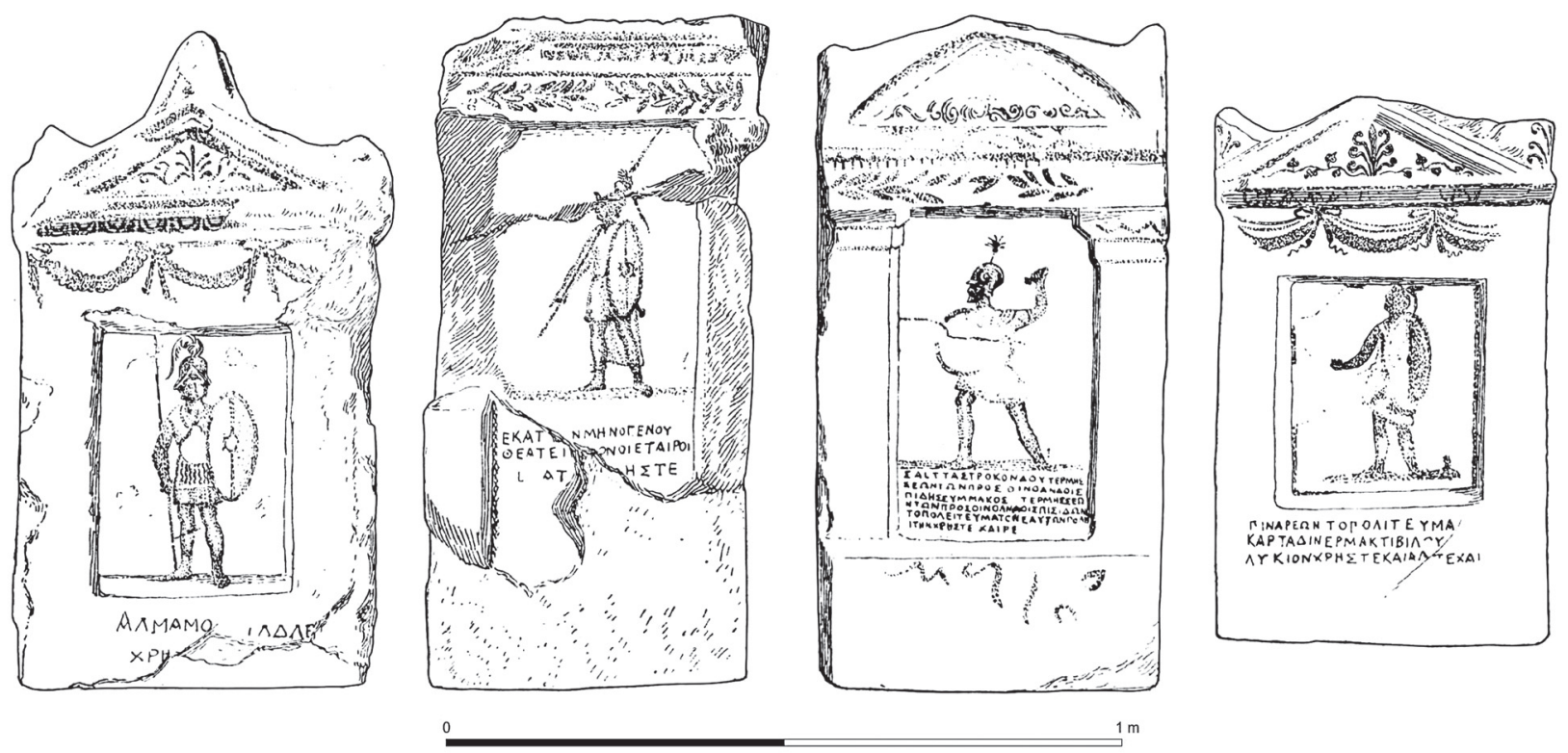

Fig. 2. Steles from Sidon (after MENDEL 1912-1914: cat. nos 105, 104, 103, 106)

The monuments took on the form of rectangular slabs about $20 \mathrm{~cm}$ thick, with a shallow rectangular niche on the front side. The better preserved steles were $60 \mathrm{~cm}$ high and about $50 \mathrm{~cm}$ wide. A simple tympanum flanked by two schematic acroteria was rendered in carving on one of the slabs. Of the other two, only one had acroteria, but neither had a tympanum in the façade (Fig. 1). The shape is overall simple and schematic. None of the steles were found in their original position. Based on excavation photographs, it can be said that at least some of the steles were reused as slabs covering later graves.

In shape, the steles from Jiyeh resemble finds from the necropolis situated in modern Saida (Fig. 2). Painted steles from Sidon were published first by
Ernest Renan. ${ }^{6}$ Further examples, all from cemeteries around Sidon (Fig. 3), were presented by several other researchers in the second half of the 19th and the first half of the 20th century. ${ }^{7}$ Similar painted steles were also found in Jerusalem, but as Charles Clermont-Ganneau demonstrated persuasively, they must have come from Sidon and were brought to Palestine most probably in the 19th century. Ch. Clermont-Ganneau also published two steles which

\footnotetext{
6 RENAN 1864: 380, 398, pl. 43.

7 PERROT 1877: 61-62; CleRMONT-GANNEAU 1877: 113; LAMMENS 1898: 109-111; PERDRIZET 1899; MACRIDY 1904a: 401-402; 1904b: 548, 550; MENDEL 1912-1914: 258-270; MEURDRAC, ALBANĖSE 1939: 50, pl. 8.
} 


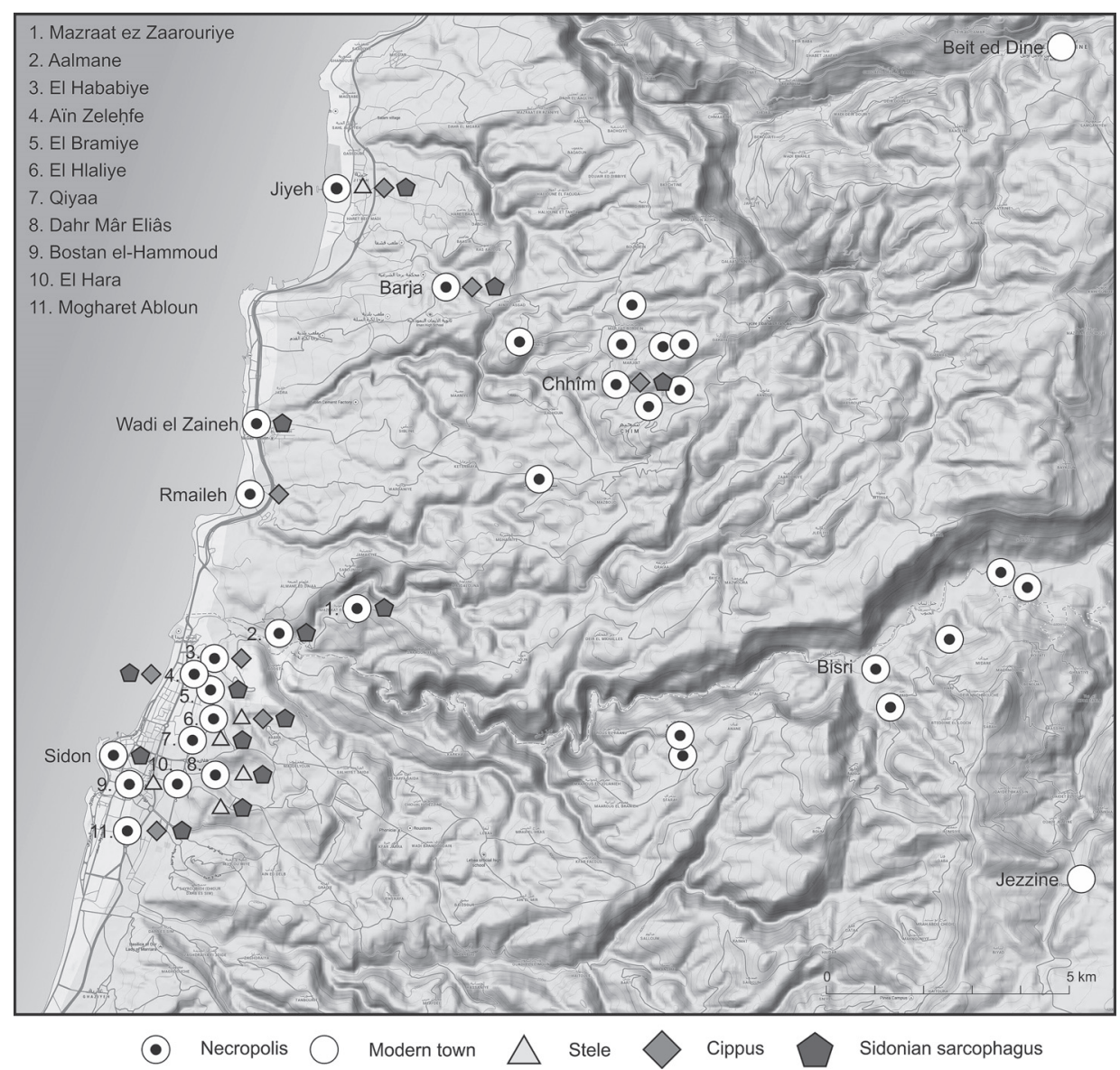

Fig. 3. Map of the northern part of the territory of Sidon (drawing M. Gwiazda)

came to the Louvre most probably from E. Renan's excavations in Sidon. ${ }^{8}$ They were made of sandstone conglomerate, rectangular or slightly trapezoid in shape, the front furnished with a shallow rectangular niche of the same kind as on the steles from Jiyeh. In most cases, the above mentioned steles were topped by a tympanum flanked by acroteria, although this was not a rule. The surface was plastered to create a ground for painted representations depicting the deceased, floral motifs and imitation architectural elements, such as columns, capitals, dentils etc. Most of the steles bore graffiti, usually in the lower part of the rectangular niche on the front side of the slab or directly below it.

Theodore Macridy suggested that the steles he found should be interpreted as cenotaphs rather than funerary monuments raised at the burial place. ${ }^{9}$ Considering the secondary deposition of most of the steles from Sidon and environs, this interpretation is nothing but tenuous at best, especially in view of a graffito published by Georges Perrot, referring to a portrait and remains of the deceased found "in this spot,"

8 CleRmont-GanNEAU 1877: 107-109, pls. 15, 16.

9 MACRIDY 1904a: 402; 1904b: 549. that is, in the tomb where the stele was discovered. ${ }^{10}$ Th. Macridy connected the steles with the period of Seleucid rule in Phoenicia, but without citing any arguments in support. ${ }^{11}$ Paul Perdrizet accepted the Hellenistic dating of the steles using a paleographic criterion, but exercised greater caution with regard to more precise attribution. He did not decide whether the mercenaries depicted on many of the Sidonian steles actually served in the armies of the Ptolemies or the Seleucids. ${ }^{12}$ Historical indications in one of the graffiti mentioning a Lacedaemonian from Gythium led Louis Jalabert to conclude that this stele, as all the others, could not predate the year $195 \mathrm{BC}$, when T. Quinctius Flaminius forced the Lacedaemonians to settle in Gythium. ${ }^{13}$ Therefore, the steles should be dated in his opinion to the times of Seleucid rule in Phoenicia. However, the dating of all the steles discovered in Sidon to the 2nd century BC is hardly tenable based on a single graffito. Considering the presence in Alexandria of painted steles from the

10 PERROT 1877: 61-62.

11 MACRIDY 1904a: 402; 1904b: 555.

12 PERDRIZET 1904: 239, 240.

13 JALABERT 1904: 14-16. 


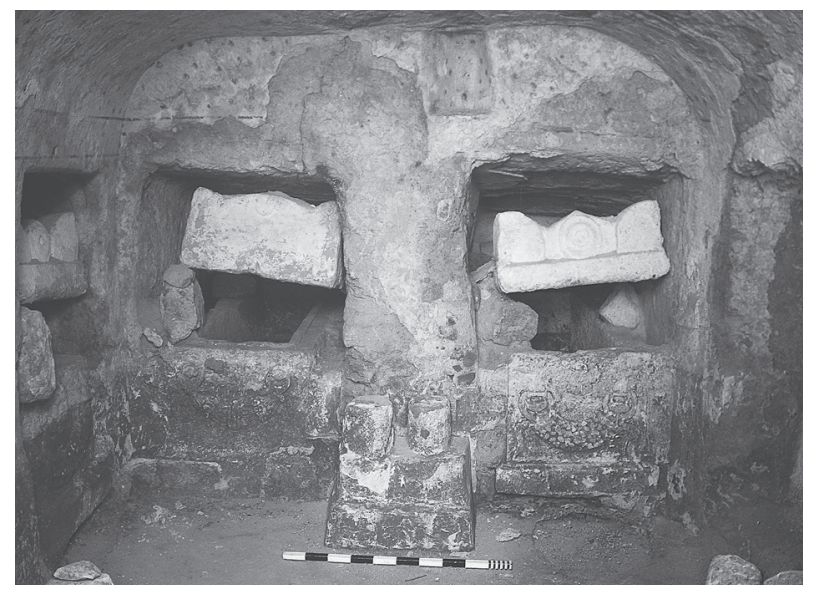

Fig. 4. Cippi and sarcophagi from a tomb in Jiyeh (photo M. Gwiazda)

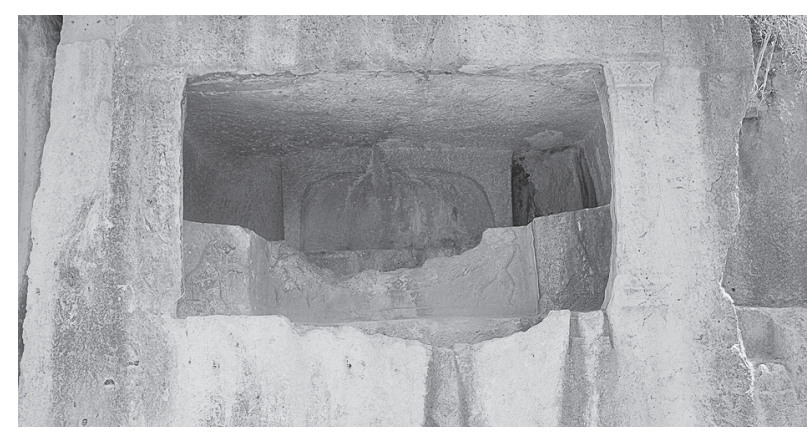

Fig. 5. Cippi and a rock-cut sarcophagus from the necropolis at Barja (photo M. Gwiazda)

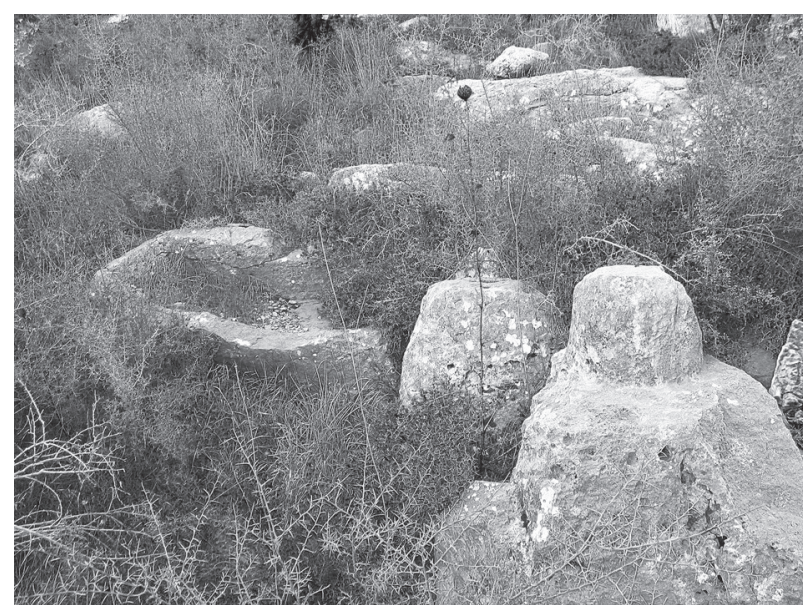

Fig. 6. Cippus cut in bedrock in the necropolis at Chhîm (photo T. Waliszewski)

3rd century $\mathrm{BC}$, resembling the Sidonian ones in form and decoration, a similarly early dating of the monuments from Phoenicia cannot be excluded. ${ }^{14}$ On the whole, however, painted steles as a form of sepul-

14 MERRIAM 1887: 261-266; BOtTI 1900: 178, 180, 190; BRECCIA 1912: 6-22, nos 9-38, pl. 22-32; BROWN 1957: 13 ff., pl. 21. chral monument were relatively rare, despite having been found at Pagasai in Thessaly and Amathus on Cyprus. ${ }^{15}$

\section{CIPPI}

Nine cippi were recorded during the exploration of the site in 2012 and 2013. These are monolithic shafts, circular or somewhat elliptical in cross-section, standing on a rectangular base. The shafts were from 15 to $27 \mathrm{~cm}$ high and had a diameter equal to, or slightly less than, the shorter side of the base, which measured from 16 to $24 \mathrm{~cm}$. The longer sides of the base were from 23 to $36 \mathrm{~cm}$ long and the base was from 13 to $21 \mathrm{~cm}$ high. Sandstone conglomerate was used to carve the monuments that were subsequently plastered all over. No evidence of either painting or graffiti was observed on any of the cippi, though it is impossible to say whether this was due to the original intent, regarding the appearance of the monument or vagaries of preservation. Two of the cippi were found in their original position inside one of the tombs (Fig. 4), where they had been set up on a small pedestal opposite the entrance, directly in front of two sarcophagi placed in the respective loculi. They may have served as markers for burials made in the central part of the chamber, below the walking level, ${ }^{16}$ but to verify this idea, it would be necessary to explore the accumulation deposited in this part of the tomb.

More than 50 sepulchral monuments of this kind were discovered in Sidon. ${ }^{17}$ The material of which they were carved included sandstone conglomerate, but also limestone and marble. ${ }^{18}$ Typically, a cippus was composed of a rectangular or cuboidal base and a shaft that was circular or elliptical in section. The more elaborate examples had a relief wreath placed high up on the shaft, most often with a central motif in the form of a diamond or rosette. Inscriptions with the name of the deceased and simple Greek formulae were found on some of the bases. More importantly, in a few cases the inscriptions included year dates

15 Pagasai: ARVAnitopoulos 1928; GRAEVE, PreusSer 1981: 120 ff. Amathus: MYRES, OHNEFALSCH-RICHTER 1899: 164-165; MURRAY, SMITH, WALTERS 1900: 93-95.

16 MACRIDY (1904a: 382) suggested the same interpretation of some cippi in one of the Sidonian tombs.

17 DE SAULCY 1853: 34, pl. 4; RENAN 1864: 381, 382-388, 397, 430, 493, pls. 22, 42; PERROT 1877: 44, 49, 50; MACRIDY 1904a: 391, 392, 398, figs. 30, 33; JALABERT 1906: 172-174; MENDEL 1912-1914: 150-157; CONTENAU 1920a: 44, 49, 50, fig. 14; 1920c: 202, 210; 1920d: 287-289; MEURDRAC, ALBANÈSE 1938: 75, 93, fig. 9 .

18 Unlike marble or limestone cippi, the ones made of sandstone conglomerate found in the necropolises around Sidon never had any relief decoration, similarly as the examples from Jiyeh. 
falling in the 2 nd century AD. ${ }^{19}$ A similar cippus is said to have been found in Salamis on Cyprus. Salomon Reinach was not certain of the findspot of this object, however, the form of which, as well as the iconography, would suggest that it may have been discovered in modern times in the environs of Sidon and subsequently transported to Cyprus. ${ }^{20}$ Cippi from Jerusalem, published by $\mathrm{Ch}$. Clermont-Ganneau, could also be associated with the Sidon necropolises. Similarly as in the case of the earlier mentioned steles, they could have been taken to Palestine in the 19 th century. ${ }^{21}$

A somewhat different form of cippus is also known from Sidon. Examples come from the necropolis in the neighborhood of Rmaileh, about $6 \mathrm{~km}$ to the north of Saida. The cippi here were carved out of the rock directly in front of the entrance to the tomb. From a photograph published by Sébastian Ronzevalle, one can estimate their height as being fairly low and determine the sections of their shafts as either circular or rectangular. They had neither distinguished bases nor decorative relief wreaths. ${ }^{22}$

In the necropolis near El Hababiye were recorded 11 rock-cut aedicules containing carved in relief depictions of cippi standing on distinguished, rectangular bases. ${ }^{23}$ Stone cippi are also known from mountain villages to the southeast of Jiyeh. Three shafts standing on rectangular bases were carved in the façade of one of the tombs in the necropolis at Barja (Fig. 5). Cippi from this necropolis, carved in typical Sidonian style with a wreath at the top of the columnar shaft, were also mentioned by E. Renan. ${ }^{24}$ At least one cippus cut in bedrock, standing next to some rock-hewn pit graves, is known from Chhîm (Fig. 6).

Drawings of three cippi, captioned as coming from Beirut, were published by Félicien de Saulcy. One of them had no base, but was furnished instead with single holes in the top and bottom ends. The shaft narrowed slightly toward the top and was topped with a cornice, below which were carved two rows of rosettes and what appears to have been a winged disk. The identification of this monument is uncertain because of the atypical form and iconography of the decoration. ${ }^{25}$ In the same plate, between two

19 RENAN 1864: 382; BEAUDOUIN, POTTIER 1879: 259, 260. In the case of cippi without year dates, which make up an overwhelming majority of the finds, a slightly earlier or later dating cannot be excluded.

20 REINACH 1886: 146.

21 Clermont-GanNeaU 1877: 102, 103, 107.

22 RONZEVALLE 1910: 189-191, fig. 17.

23 El Hababiye is nowadays a district of Saida. RoNZEVALLE 1910: 191, figs. $18-20$.

24 RENAN 1864: $511-512$.

25 DE SAULCY 1853: pl. 4. cippi identified as coming from Sidon, there was yet another monument with typically Sidonian decoration in the form of a wreath with a rosette. In the report from his travels, F. de Saulcy failed to mention the place and circumstances of the discovery of these cippi, hence it cannot be excluded that, in view of the form of the second described cippus, the monuments were actually found in Sidon and that the caption is a mistake for reasons not to be fathomed today. It should be noted that to date, excavations in Beirut did not bring to light any sepulchral markers of this kind.

Cippi were recorded at other Phoenician sites too, for instance, in the neighborhood of Byblos and Amrit, as noted by E. Renan, who also observed that they differed in form from the Sidonian examples. ${ }^{26}$ Monuments of this kind were present also in other cities on the Mediterranean coast, but they were never of the same form as the examples from Sidon and Jiyeh. ${ }^{27}$ They were most commonly cylindrical in shape, more seldom upturned cones, standing on circular bases. Dating based on paleographic criteria places them most frequently in the $1 \mathrm{st}-2$ nd or 2 nd $-3 \mathrm{rd}$ and $3 \mathrm{rd} / 4$ th century AD.

The function of the cippi found in sepulchral contexts is not quite clear. They are believed to have played the role of nefesh or may have served simply as tomb markers, but in either case there are still no convincing arguments either for or against these interpretations. $^{28}$

\section{SARCOPHAGI}

Sarcophagi are the most numerous category of finds from the necropolis at Jiyeh. ${ }^{29}$ All were made of local stone commonly found in this part of the Phoenician coast. Sandstone conglomerate prevailed, with a much rarer occurrence of limestone and limestone breccias. Only three sarcophagi are still to be seen inside tombs. In all cases, the coffins were rectangular, the lids in the form of either pitched roofs or rounded, or flat in section. Four corner acroteria were present in the case of the first two shapes of the lids.

There were three principal forms of the coffin. One had no base or decoration on the sides (Fig. 7), while another had a base and two round or square bosses on either one or both long sides (Fig. 8). Both shapes were made of local sandstone conglomerate

26 RENAN 1864: 200, 206, 231, pl. 5.

27 E.g., Cyprus: COLONNA CECCALDI 1874: 79, pl. 3; MENDEL 1912-1914: 381; MASSON 1969: 362 ff.; BUCHHOLZ 1973: 374-379; AUPERT 1980: 238-254, 257; Syria: SAADE 1976: figs. 4, 16, 24; Cilicia: BEL 2012b: fig. 345.

28 RONZEVALLE 1910; BEL 2012b: 355; YON 2012: $117 \mathrm{ff}$.

2916 sarcophagi were recorded in 2012 and 2013, scattered over the northern part of the site. 


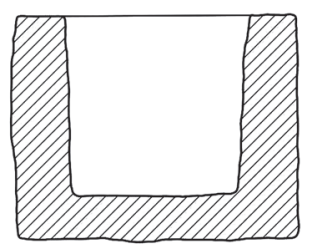

$1 \mathrm{~m}$

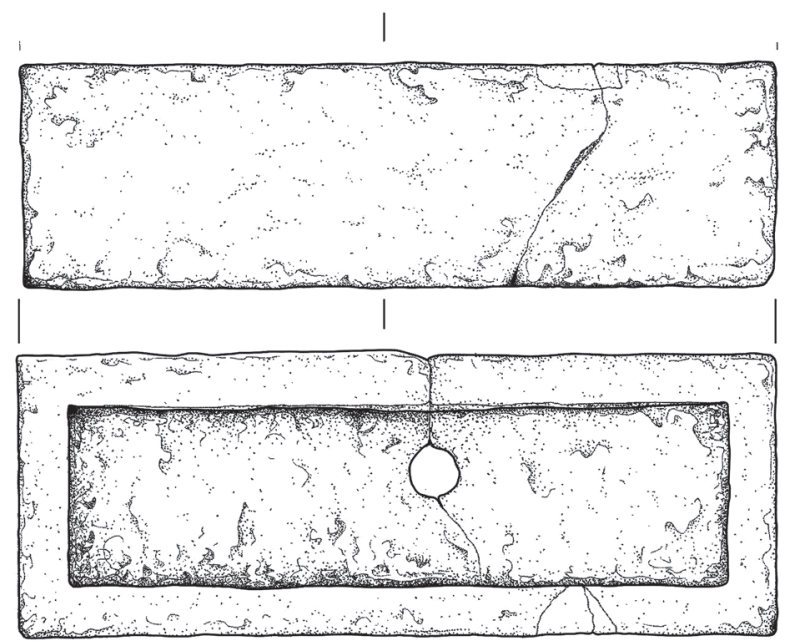

Fig. 7. Undecorated sarcophagus from Jiyeh (JY 29-12-S-MR) (drawing M. Makowska)

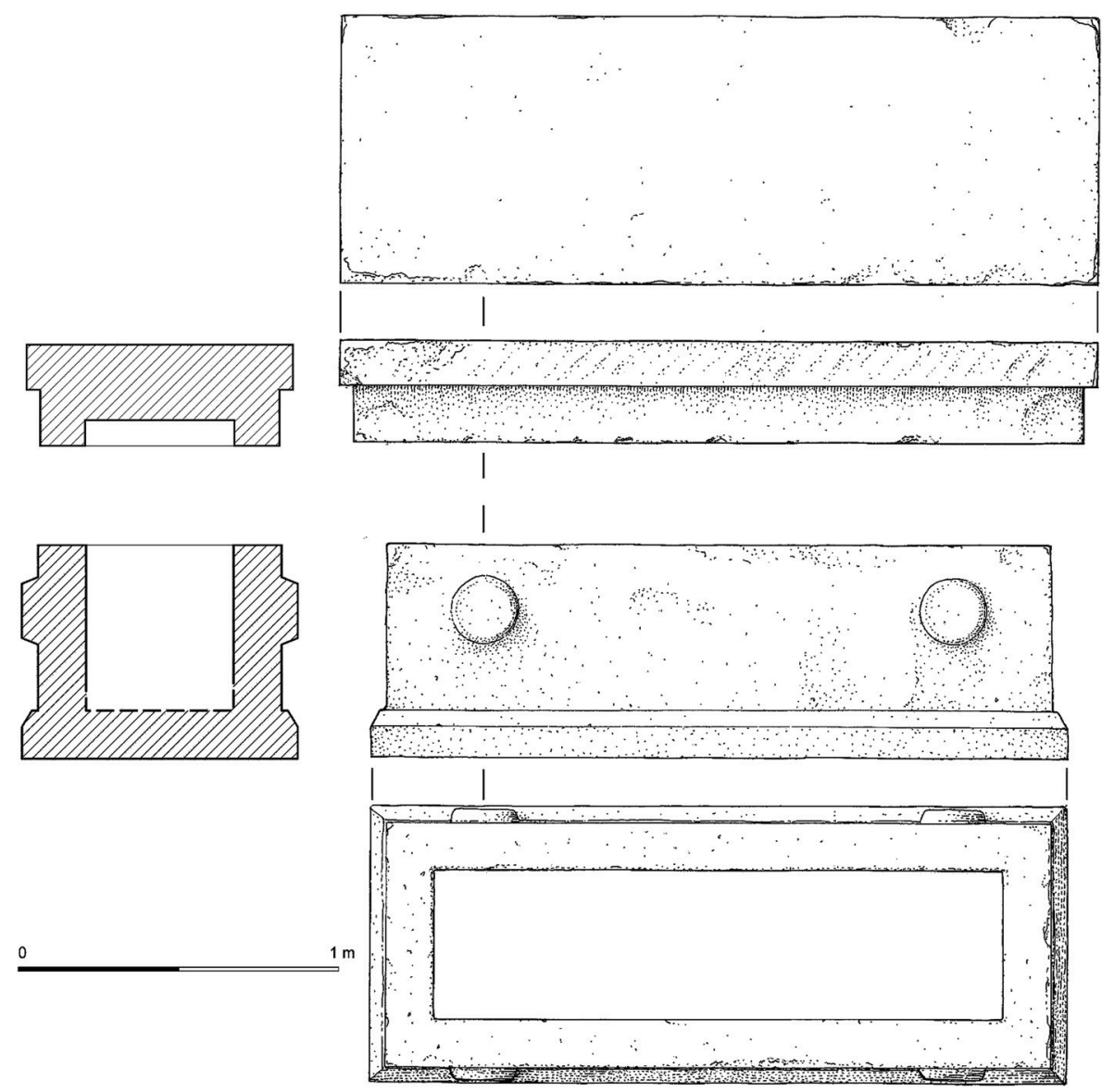

Fig. 8. Sarcophagus with round bosses from Jiyeh (JY 4-09-S-MR) (drawing M. Puszkarski)

exclusively. Limestone and breccia were used for four sarcophagi making up the third distinguished type, three of which were still found inside a tomb (Fig. 4). Only one of the short sides was visible in the case of these three sarcophagi and it was decorated with garlands tied with fillets to rings held in a lion's jaw. Rosettes can be seen in the middle of each garland, above it. The lids of these sarcophagi were only partly finished. The acroteria were shaped but not decorated with palmettes. Between them, in the tympanum, were concentric circles that may be interpreted as blank rosettes (Fig. 9). The fourth sarcophagus had a lid made of limestone breccia with reddish cement, partly carved, but without palmette decoration on the acroteria and blank round shields on the shorter sides (Fig. 10). The coffin itself was made 

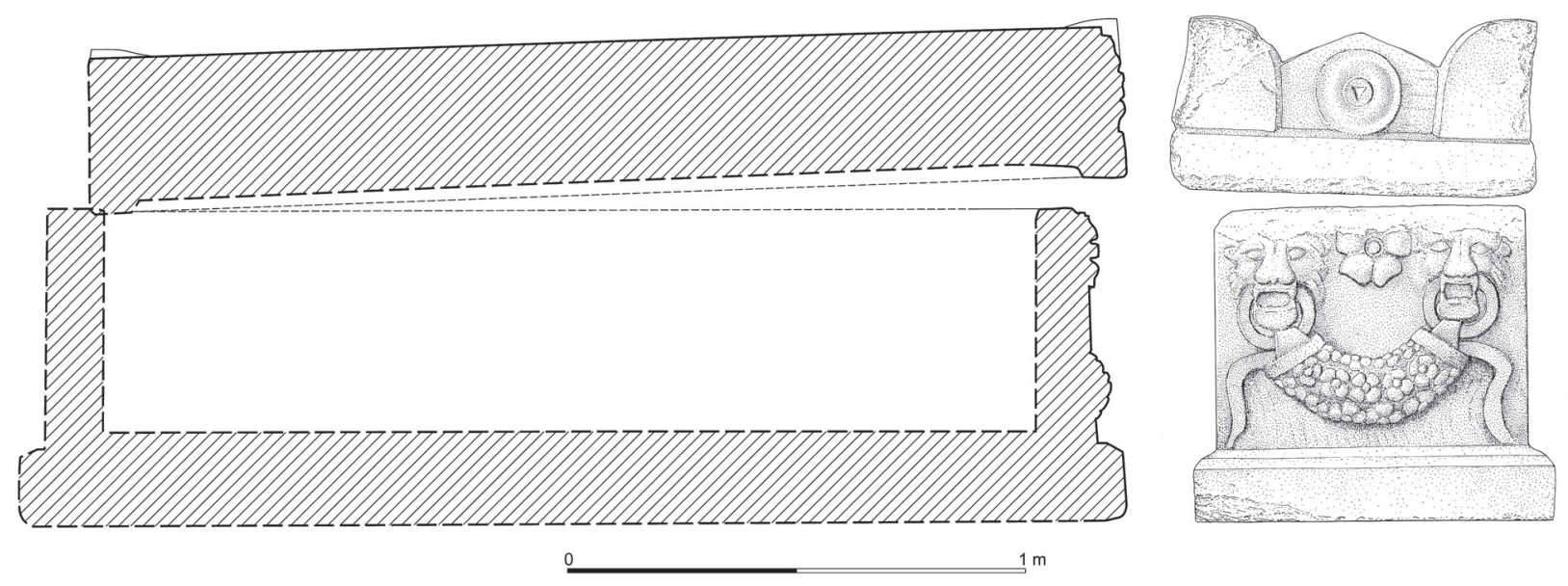

Fig. 9. Sarcophagus with garland decoration from Jiyeh (JY 3-09-S-MR) (drawing M. Puszkarski)
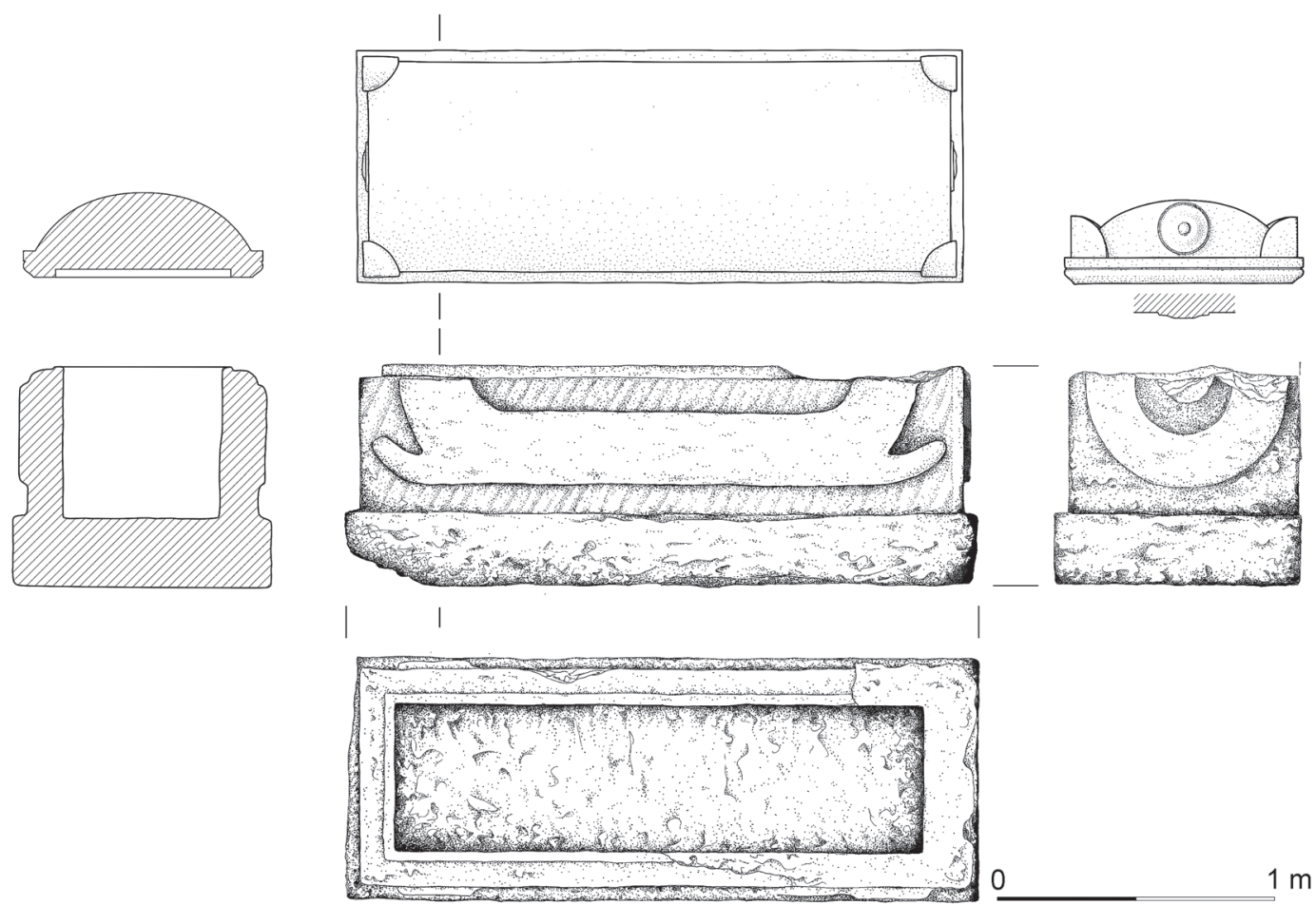

Fig. 10. Unfinished sarcophagus with garland decoration from Jiyeh (coffin: JY 2-12-S-MR; cover: JY 4-12-S-MR) (drawing M. Puszkarski, M. Makowska)

of ordinary limestone. The two longer sides and one of the shorter sides were supposed to be decorated, as indicated by the broad arched bands which would have been carved into garlands tied to rings held in the mouths of lion protomes. The arched band on the short side is probably also another unfinished garland.

The best parallels for the form, decoration and material of the sarcophagi from Jiyeh come from the Sidonian necropolises and modern Wadi el Zaineh (cf. Fig. 3). E. Renan was the first to publish objects of this kind, both the coffins without bases and those furnished with a base and decoration in the form of round and square bosses. Included in his plates are also sarcophagi with unfinished garland decoration..$^{30}$ Georges Contenau, too, published sarcophagi from a Sidonian cemetery, either made of sandstone conglomerate, set on a simple base and without decoration on the sides, or furnished with a pitched roof and acroteria, and decorated with two square bosses on the longer side. ${ }^{31} \mathrm{~A}$ coin of most probably Elagabalus in

30 RENAN 1864: 504, 505, 516.

31 CONTENAU 1920b: 150, 151, fig. 49; 1920c: 209, 210, 213, 214, figs. 66,73 . 


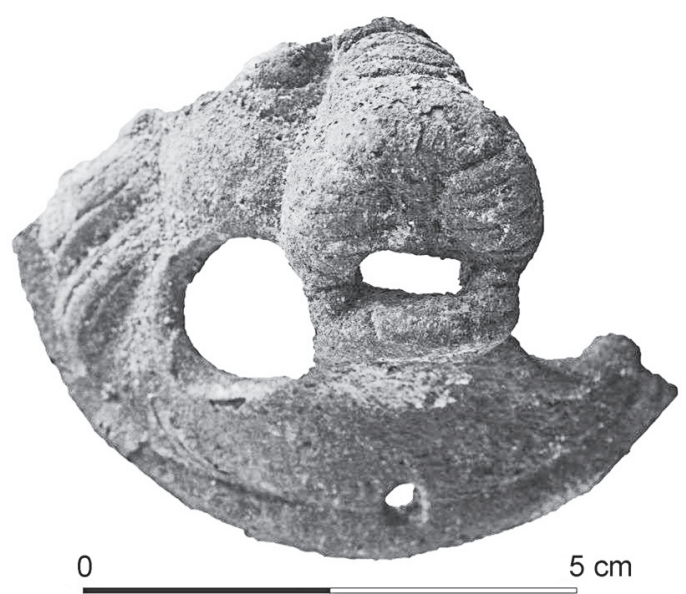

Fig. 11. Fragment of a copper-alloy lion protome from Jiyeh (MNB43809) (photo B. Wójcik)

one of these sarcophagi provided an ante quem date for this assemblage. ${ }^{32}$

The lion protome on three sarcophagi from Jiyeh was relatively rare in Phoenicia and in other parts of the Roman Empire. Moreover, in the known examples from Tyre, Bosra, Italy, Asia Minor and Athens, the lions do not hold rings with garlands tied to them in their mouths. ${ }^{33}$ Such a motif is common, however, on sarcophagi from Sidonian burial grounds and appeared also on a 3rd century AD sarcophagus from Palmyra. ${ }^{34}$ Furthermore, lion protomes holding a ring with garlands tied to it occur on lead coffins of Sidonian production and, more importantly, no others. ${ }^{35}$ The origins of this motif should be linked to the practice of mounting ring handles on wooden coffins. Simple ring handles occurred in Phoenician tombs starting from at least the end of the Iron Age and were used subsequently in the Hellenistic and Roman periods. ${ }^{36}$ More elaborate rings with lion protomes appeared in Syria in the 1st century $\mathrm{AD}$ and so far Sidon is the findspot of the largest number of objects of this kind. ${ }^{37} \mathrm{~A}$ fragment of a bronze handle of this type was excavated at Jiyeh

32 Contenau 1920c: 214.

33 CHÉHAB 1968: 71, pl. 44; KOCH 1977: 112-115; WEBER 1989: pl. 61. 3-4; КOCH 1989b: 174, pls. 45b, 46d, 46e; STROSZECK 1994: 222, 232-235, pls. 78-89.

34 RENAN 1864: 453, pl. 61; MACRIDY 1904a: 393, 394, 395; MENDEL 1912-1914: 76-78, 149, 406, 407; CONTENAU 1920a: 33, 35-43, 46-48, figs. 9b, 10, pl. 5.2; 1920c: 210, 222, 223, 227, fig. 67; MEURDRAC, ALBANĖSE 1938: 75-77, 81, 82, 94, fig. 3 pl. 6; 1939: 41, 46, 48, 50, fig. 2, pls. 4c, 4d, 7a, 7b; KoCH 1977: 116, fig. 5; BEL 2012a: 340, 341, figs. 329, 331; WIELGOSZ 1997: 71, pl. 4.1; 2004: 933, fig. 5.

35 CHÉHAB 1934: 343, pls. 42, 43. Cf. RAHMANI 1999.

36 CONTENAU 1920b: 137, 139, fig. 40; 1920c: 208; STUART 2001-2002: 89 .

37 RENAN 1864: 441, 447; CONTENAU 1920a: 33; MEURDRAC, ALBANÈSE 1938: 83; SEYRIG 1953: 14, 15; WEBER 1989: 7-10, $65,66$.
(Fig. 11). ${ }^{38}$ According to Guntram Koch, these objects were models for the decoration appearing on Sidonian sepulchral monuments. ${ }^{39} \mathrm{He}$ also believed that the lion protome holding a ring with garlands tied to it constituted a motif that remained in use until the second quarter of the 2nd century $\mathrm{AD}$, when it was replaced by representations of Amors, Nikai and bull's heads. ${ }^{40}$ The change in the decorative repertoire expressed the partial adoption of decorative motifs from production centers in Asia Minor and Greece in place of local Sidonian compositional designs.

At the present stage of research, the sarcophagi from Jiyeh can be dated solely based on the results of a study of analogous objects from Sidon originating from the $1 \mathrm{st}-3 \mathrm{rd}$ century AD. Analyses of coins, inscriptions and ceramics supply a ground for the dating of these sarcophagi, ${ }^{41}$ and it should be noted that iconographic parallels for the sarcophagi with lion protomes led some researchers to attribute these particular stone coffins more likely to a period from the 1st century $\mathrm{AD}$ through the second quarter of the 2nd century AD. ${ }^{42}$

\section{DISCUSSION AND CONCLUSIONS}

The dating of the steles and garland sarcophagi discovered in Jiyeh to, respectively, the turn of the 3rd century $\mathrm{BC}$ and the 1 st through the early 2 nd century $\mathrm{AD}$ indicates that the necropolis operated at the same time as the nearby ceramic workshops and that it was certainly not established later, as has been suggested at some point. ${ }^{43}$ The proximity of a workshop area and cemetery is nothing unusual, suffice it to mention Berytus, for example. ${ }^{44}$ By the same and in view of the ancient practice to locate burial grounds outside the towns and villages, ${ }^{45}$ it was possible to trace the

38 The object was discovered during the Lebanese excavations directed by Roger Saidah in 1975. It is kept now in the stores of the Museum in Beirut and is being studied by Agnieszka Szulc-Kajak, to whom I am grateful for permission to publish the photograph.

39 KOCH 1977: 117-118.

$40 \mathrm{KOCH}$ 1977: 119. Other motifs, borrowed in all probability from Asian Minor sarcophagi, include the grapevine leaf below the garland and the Medusa heads, cf. MEURDRAC, ALBANĖSE 1938: pl. 6.

41 CONTENAU 1920c: 198-199; 1924: 132; MEURDRAC, ALBANÈSE 1938: 77. I thank Urszula Wicenciak for consulting pottery datings published by M. Meurdrac and L. Albanèse.

42 CONTENAU 1920a: 40-43; PICARD 1933: 319; KOCH 1977: 120 .

43 WICENCIAK et al. 2003: 129-130; DOMŻALSKI et al. 2005; WICENCIAK 2014. Remains of domestic architecture just $200 \mathrm{~m}$ to the south of the necropolis come from the same period.

44 Kowatli, CURVERs 2006.

45 For the location of Graeco-Roman period cemeteries in Phoenicia, see TCHOREK 2002: 52; VAN ESS, PETERSEN 2003: 91; DE JONG 2001-2002: 301-302; 2010: 622-623. 


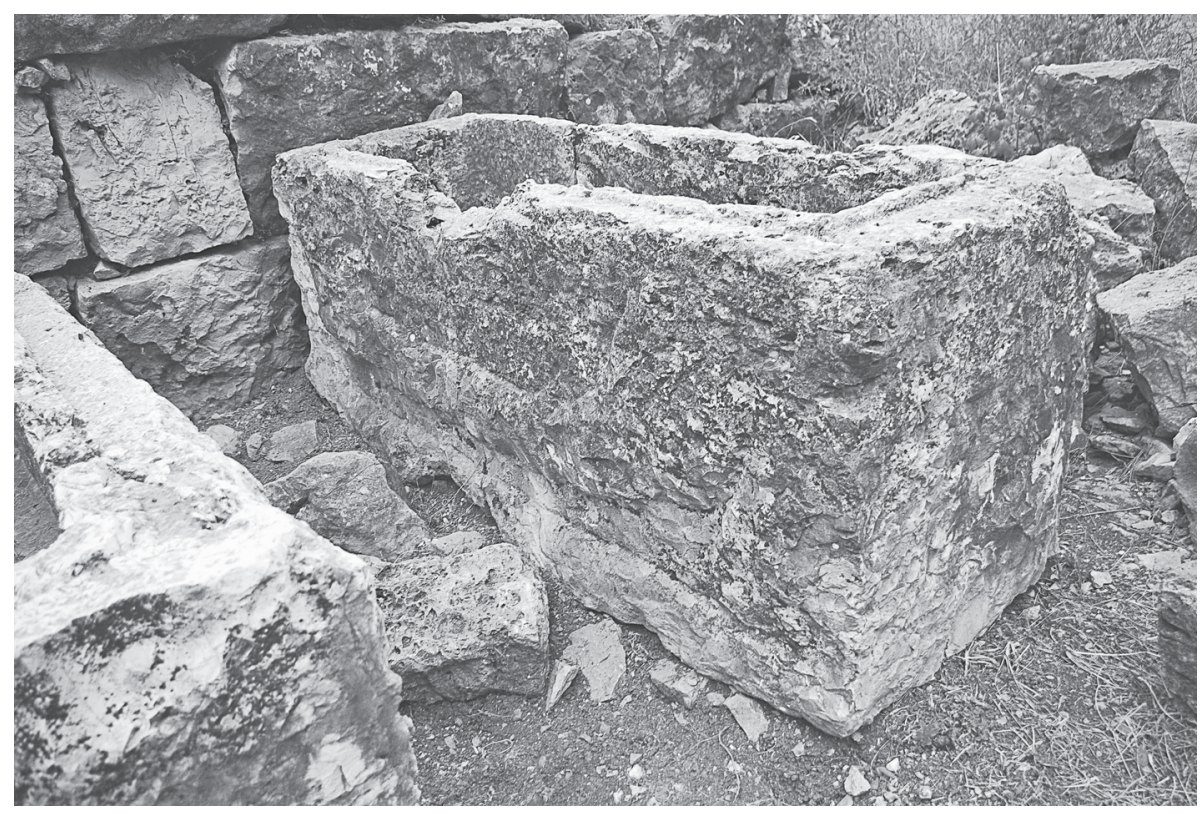

Fig. 12. Sarcophagus with garland decoration from Chhîm (photo M. Antos)

northern boundary of the settlement in the Hellenistic and early Roman periods. More importantly, a survey to the north of the necropolis and workshops revealed no evident traces of settlement, with the exception of two wells and a presumed quarry which could not be dated. ${ }^{46}$ The presence of an early Byzantine cemetery on top of the Hellenistic and early Roman remains should also be noted; it was manifested by paintings with Christian motifs in some of the recorded tombs. ${ }^{47}$ There can be no doubt, therefore, that the northern border of the ancient settlement of Jiyeh remained in approximately the same place for about a millennium.

In the light of this evidence, one is entitled to consider the reasons for the appearance of sepulchral monuments of the same kind in Jiyeh and Sidon. Written sources point to close ties between the two centers. According to Pseudo-Scylax, the territory of Sidon in the 4th century BC encompassed Porphyreon. ${ }^{48}$ Thanks to Polybius and Joseph Flavius, the border between the lands of Sidon and Berytus in the early Roman period can be set on the Nahr el-Damour (ancient Tamyras/Damouras) river, that is, between Jiyeh and Khan Khalde (ancient Heldua). ${ }^{49}$

46 Personal communication, Mahmoud El Tayeb. The author visited the area in 2013 and also observed no evident traces of settlement on this spot.

47 Information based on unpublished documentation of salvage excavations carried out in this area.

48 PSEUDO-SCYLAX, Periplus 104; LIPIŃSKI 2004: 268-269, 289-295.

49 On the borders of Sidonian territory: CLERMONT-GANNEAU 1904; DUSSAUD 1927: 44-47; REY COQUAIS 2005: 85; ALIQUOT 2009: 56, note 112. The southern border of Sidon lay
The early Byzantine inscriptions from the two settlements, which contain dates put down in the respective eras of Sidon and Berytus, ${ }^{50}$ also speak in favor of such a territorial division. There are no known events that would have indicated any change of this border in the course of more than a millennium. Consequently, the settlement at Jiyeh may be assumed to have belonged to the chora of Sidon. Finds of the Hellenistic painted steles and Roman garland sarcophagi with lion protomes fit very well into this territorial context (Fig. 3), pointing to an artistic link between Sidon and its economic hinterland. A good example of the cultural distinctness of the territory lying north of Jiyeh is the site of Khan Khalde, situated about $17 \mathrm{~km}$ from Jiyeh. Visiting the Roman necropolis there, F. de Saulcy documented a sarcophagus with panel decoration that has the closest parallels in Heliopolis, a center in the orbit of Berytus until the reign of Septimius Severus. The cippi from Khan Khalde are also different from those known from Jiyeh, Chhîm, Barja and Sidon itself. They have shafts that are rectangular in section, not round or elliptical. ${ }^{51}$

in the vicinity of the Zahrani river. The area cannot be included in the present discussion because of a much poorer record of archaeological investigations in this part of the land.

50 Jiyeh: ABOU DIWAN 2009: 118-119; 2014. The date on a Byzantine mosaic from the Chhîm village lying about $8 \mathrm{~km}$ southeast of Jiyeh was written according to the same dating system: ALPI 2002: 47-48. Khan Khalde: DUVAL, CAILlET 1982: 354, 365-366, 379, 392-394; REY COQUAIS 1982: 405-408.

51 DE SAULCY 1853: 26-27, pl. 3; VAN ESS, PETERSEN 2003: 92. On the relation between Heliopolis and Berytus, see SAWAYA 2009: 238-240. 


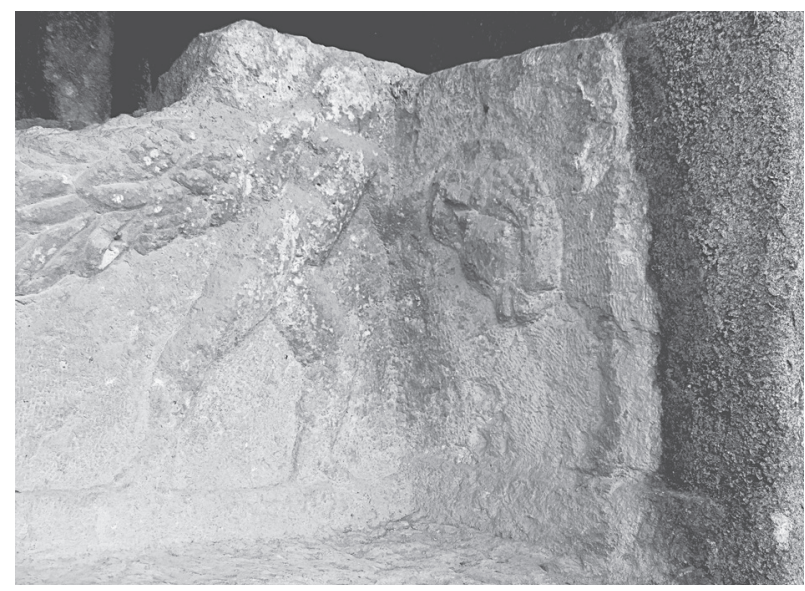

Fig. 13. Detail of a rock-cut sarcophagus from the necropolis at Barja (photo M. Gwiazda)

The presence of artistically homogeneous steles, cippi and sarcophagi in the territory of Sidon does not in itself explain the reasons for this homogeneity. Were the objects found in Jiyeh imported to the settlement or were they worked in workshops at the site, imitating products coming from the nearby center? Or was there perhaps an itinerant workshop operating in Sidon and its environs? Macroscopic observation of the worked stone objects from Jiyeh and Sidon permits a general and hardly credible statement of the similarity of sandstone conglomerate from both sites, which differed only insignificantly in color of the stone. ${ }^{52}$ It could point to the raw material being quarried locally near the cemeteries in question. Polish-Lebanese excavations at Jiyeh have demonstrated a far-going labor specialization in the area from the Hellenistic through the early Byzantine periods, associated with differentiated local craftsmanship and agricultural production, and ensuring a substantial degree of economic self-sufficiency. ${ }^{53}$ None of the evidence, however, confirmed this state of affairs for the production of sepulchral monuments. Without petrographic analyses comparing samples from ancient quarries with the stone of the objects in question it is impossible to be certain as to whether given objects were imported or produced on the spot. ${ }^{54}$

52 In the case of objects made of limestone and breccia, the author cannot be sure of there being any differences between objects found in Sidon and Jiyeh. Sidonian cippi and sarcophagi in the stores of the Department of Antiquities in Saida and the stele of Robia on display at the Museum in Beirut were studied by the author in 2013. Most of the Sidonian steles are now held in the collection of the Archaeological Museum in Istanbul, but in this case the restoration of plaster covering the surfaces of these steles makes any examination of the stone material impossible.

53 GWIAZDA 2011-2012.

54 The quarry producing the stone from which the sarcophagi were made has been identified most probably in Mogharet Abloun (southern Saida): CONTENAU 1920a: 26. On other quarries in this region, see BADAWI 2002: 315-317; JAKUBIAK 2011: 299.
The two sarcophagi in evidently unfinished state from the Jiyeh necropolis are by themselves not sufficient evidence to say either way about the issue of potential imports to the site. One of these stone coffins made of sandstone conglomerate had two round bosses on the long side, and on the short side an arched band that was actually a roughly carved garland. The other sarcophagus, carved in limestone, had sketched garlands on both the long and short sides (Fig. 10). Sarcophagi with unfinished garland decoration are known also from Chhîm (Fig. 12), Wadi el Zaineh and Sidon itself. ${ }^{55}$ These objects need not be testimony of local production as the ancient world in the Mediterranean witnessed a lively trade in unfinished sarcophagi and their use for burials when necessary. ${ }^{56}$ On the contrary indeed, these objects attest to the operation of a workshop(s) producing sarcophagi in large numbers and shipping them, finished or unfinished, depending on the contracts with direct buyers. Naturally, production of goods in large quantities is determined by a proportionately large demand. Only Sidon could guarantee a constant and relatively large stream of orders. Moreover, evidence of quarries associated with the production of sarcophagi is available only from the immediate neighborhood of this city. ${ }^{57}$

Despite the fact that all the Jiyeh finds are movable, one can consider the possibility of an itinerant sculpting workshop in this part of Phoenicia. One of the several rock-cut tombs in the necropolis at Barja, situated approximately $16 \mathrm{~km}$ northeast of Sidon (cf. Fig. 3), contained a richly decorated sarcophagus cut in bedrock inside the chamber. The decoration in relief consisted of two male figures holding ram protomes and a laurel garland in their hands, and two seated lions with raised paws on either side (Figs 5 and 13). ${ }^{58}$ The background in these representations was dressed with a broad chisel that left a series of shallow and relatively short grooves. ${ }^{59}$ A similar decoration was recorded on a sarcophagus from Dahr Mâr Eliâs (eastern part of modern Saida, cf. Fig. 3). A floral garland appeared on its longer side, suspended from ram protomes shown in profile, similarly as in the relief from Barja. The sarcophagus was dated on stylistic grounds to the late 2 nd century AD. ${ }^{60}$

55 RENAN 1864: 504, 516, figs on p. 505 and 516; CONTENAU 1920c: 210, fig. 67; TCHOREK 2002: 52.

56 More on the mass production and production-to-stock of Roman sarcophagi, see RUSSELL 2011.

57 CONTENAU 1920a: 26.

58 Cf. RENAN 1864: 510-511; EL TAYEB 2002: 11.

59 The same kind of finishing traces on flat surfaces can be seen also on limestone sarcophagi found at Jiyeh and in the lapidary of the Department of Antiquities in Sidon.

60 MEURDRAC, ALBANÈSE 1939: 37-41, pl. 4a-b. 
Despite differences in iconography and composition, the decoration on the sarcophagi from Barja and Dahr Mâr Eliâs is very similar in style and the ram protomes are practically identical. It could mean that the same workshop and perhaps even the same craftsman were responsible for their execution. The compositional and iconographic differences in this case are hardly surprising. No two Roman cippi and sarcophagi from Sidon and vicinity bear decoration that would be completely identical as a whole. For example, there are four sarcophagi with iconographically very similar female griffins with one paw placed on a wheel, depicted on the short sides. In all four cases, however, the decoration of the other sides differed. The one described above had a garland suspended on ram and bull protomes, and the heads of Papposilenus and Pan in relief next to it. Garlands and heads of Medusa appeared on the next. On the third sarcophagus, one of the longer sides bore a garland held up by Amors, while the opposite side was decorated with the head of Medusa between ram protomes with garlands joining them. Last but not least, the long side of the fourth sarcophagus had a relief depicting an open shell flanked by Amors and marine creatures. ${ }^{61}$ These four examples demonstrate that sculptors decorating sarcophagi used a limited iconographic repertoire to give their customers an unlimited series of original and unique products.

Further support for the theory that the sarcophagus from Barja was carved by itinerant craftsmen derives from the fact that in terms of quality of execution it finds no match in this necropolis. It follows that the settlement could have hardly assured enough customers to support the operations of a high-quality workshop on the spot for a longer period of time. The situation would have been similar in Jiyeh, Wadi el Zaineh and Chhîm, where the number of richly decorated sarcophagi is insignificant. Taking into consideration a short distance separating these localities from the metropolis, no more than $17 \mathrm{~km}$, it seems more probable that the high-quality sarcophagi were imported to the sites in the finished state or that, sporadically, craftsmen from Sidon would have traveled outside the city to complete specific orders. The alternative in the form of high-quality workshops existing in all these villages is not convincing in this light, creating, as it would have, a situation of unprofitable surplus supply.

61 MACRIDY 1904a: 397, pl. 9.1-3; CONTENAU 1924: 126, pl. 36; MEURDRAC, ALBANĖSE 1939: 37-41, pl. 4a-b. See also the repeated motif of a sitting Psyche with head in her hand on the shorter sides of three other Sidonian sarcophagi: MEURDRAC, ALBANÈSE 1939: 41, 49-50, pls. 4c-d, 7c-d, as well as on two tympana of sarcophagi lids: RENAN 1864: 380 ; and cippi of Zenon: PARLASCA 1982: pl. 22.1.
Sidon's artistic independence from other early Roman craft centers can be observed also in the case of local manufacture of lead coffins. The most common decorative motifs on these coffins are garlands tied to rings held in the mouths of lion protomes, borders composed of scrolling grapevine and representations of Psyche. Practically all the known finds can be traced to the cemeteries in the immediate vicinity of Sidon. ${ }^{62}$ One such coffin was discovered in the course of Polish-Lebanese salvage excavations at Jiyeh in $2004,{ }^{63}$ but not one has ever been recorded from the burial grounds in the mountainous regions of the Sidonian chora. ${ }^{64}$ This example shows the uneven distribution of objects associated with Sidonian workshops in the city's hinterland (cf. Fig. 3). It is evident also in the case of the tombs forms. For example, early Roman tombs with loculi are known from Sidon, Jiyeh (personal observation) and Chhîm, but were not observed in the necropolis at Barja. ${ }^{65}$ Regional differences in the distribution of the diverse elements connected with burial practices in Sidonian territory must remain largely unexplained for now. Nevertheless, in the case of steles, cippi and decorated sarcophagi, it is evident that a larger number of objects of this kind is concentrated in the coastal zone that was surely more closely integrated with the metropolis culturally and economically for topographical reasons, if nothing else. As regards Chhîm, where just a single decorated sarcophagus that can be associated with a Sidonian sculpting workshop was discovered, it might be considered an example of weaker integration due to the location of the village in the not easily accessible mountainous terrain.

All the sarcophagi from Jiyeh were made of locally available stone. There was no example of marble or any other imported stone. The lesser affluence of

62 CHÉHAB 1934: 342-343, pls. 42-43, 46; 1935: 58.

63 Unpublished. For the time being held in the stores of the Polish-Lebanese Archaeological Mission at the ancient site of Chhîm, where it could be studied by the present author.

64 The observation draws on the published results of surveys carried out by M. El Tayeb in Iqlim el Kharoub province (EL TAYEB 2002), K. Jakubiak in the Auali Valley (JAKUBIAK, NESKA 2005; 2007; JAKUBIAK 2011), and at the site of Chhîm (TCHOREK 2002: 52). The same can be said of clay coffins imported most probably from the southeastern coast of Asia Minor or the neighborhood of Antioch, found exclusively within a radius of a few kilometers from Sidon: MACRIDY 1904a: 397; 1904b: 563; CONTENAU 1920b: 150-151; 1920c: 200, 202, 207; MEURDRAC, ALBANĖSE 1938: 78, 82; 1939: 44. Finds of this kind are known also from other Phoenician towns, such as Arados, Berytus, Tyre, Akko. Coffins of this kind are dated to a period between the second half of the 2 nd and the first half of the 4th century AD; more on the subject, see AVIAM, STERN 1997; PARKS, AVIAM, STERN 1997; SHAPIRO 1997.

65 Sidon: CONTENAU 1920b: 149-150, figs. 47-48; Jiyeh: personal observation; Chhîm: ORTALI-TARAZI, STUART 2002. 
Jiyeh inhabitants in antiquity is hardly a justifiable explanation for this state of affairs, considering that so far only four sarcophagi made of imported stone have been attested in all of the Roman-age necropolises of Sidon. ${ }^{66}$ One should also take note of Mosche Fischer's study of imported marble sarcophagi in Palestinian territory, which has demonstrated that the size of the trade in objects of this kind imported to the
Levant started to grow only in the early 3rd century AD. ${ }^{67}$ It cannot be excluded that the same applied to the Sidonian cippi of marble, which should not be dated earlier than the 3rd century AD. ${ }^{68}$

Antiquity of Southeastern Europe Research Centre,

University of Warsaw

Krakowskie Przedmieście 32

PL - 00-325 Warszawa

\section{REFERENCES}

Abou Diwan, G. 2009. "L'ère d'autonomie et le calendrier de Sidon. Une révision à la lumière d'une nouvelle inscription d'époque byzantine," ZPE 170, 113-126.

Abou Diwan, G. 2014. “A propos de l'usage de l'ère sidonienne à Porphyréôn (Jiyeh et Nabi Younès) à l'époque protobyzantine," Chronos 30, 145-163.

Aliquot, J. 2009. La vie religieuse au Liban sous l'Empire Romain (Bibliothèque archéologique et historique 189), Beyrouth.

Alpi, F. 2002. "L'inscription de la dédicace," in: Waliszewski, Ortali-Tarazi 2002, 47-48.

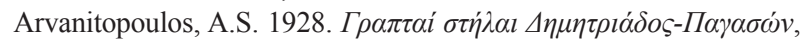
Athenais.

Aupert, P. 1980. "Inscriptions d'Amathonte, II," BCH 104.1, $237-258$.

Aviam, M. and E.J. Stern. 1997. "Burial in Clay Sarcophagi in Galilee during the Roman Period," 'Atiqot 33, 151-162.

Badawi, H. 2002. "Les carrières littorales de la Phénicie romaine," in: M. Khanoussi, P. Ruggeri, and V. Paola (eds.), L'Africa romana: lo spazio marittimo del Mediterraneo occidentale: atti del 14. convegno di studio, 7-10 dicembre 2000, Sassari, Italia (Collana del Dipartimento di Storia dell'Università degli Studi di Sassari, N.S. 13.1), Roma, 305-322.

Beaudouin, M. and E. Pottier. 1879. "Collection de M. Péretié: inscriptions," $B C H$ 3, 257-271.

Bel, N. 2012a. "Les sarcophages," in: N. Bel et al. (eds.), L'Orient romain et byzantine au Louvre, Paris, 338-345.

Bel, N. 2012b. "Les cippes de Sidon," in: N. Bel et al. (eds.), L'Orient romain et byzantine au Louvre, Paris, 354-357.

Botti, G. 1900. Catalogue des monuments exposés au Musée Gréco-Romain d'Alexandrie, Alexandrie.

Breccia, E. 1912. La Necropoli di Sciatbi (Catalogue général des antiquités égyptiennes du Musée d'Alexandrie - nos 1-625), Caire.

Brown, B.R. 1957. Ptolemaic Paintings and Mosaics and the Alexandrian Style (Monographs on Archaeology and Fine Arts 6), Cambridge, Mass.

Buchholz, H.-G. 1973. "Tamassos, Zypern, 1970-1972," AA, 295-388.

66 Three marble sarcophagi: RENAN 1864: 365, pl. 45, fig. 1; CLERMONT-GANNEAU 1888: 162-164, pls. 7-8; MEURDRAC, ALBANĖSE 1939: 47-48, pl. 6a; BEL 2012a: 339, fig. 330, and one made of basalt: CONTENAU 1920b: 151-152, figs. 52-53. Of the three marble sarcophagi, two may be considered, based on their decoration, as being fully formed in their land of origin, either Greece or Asia Minor. The third one, with a wreathed cippus carved in relief on one of the shorter sides, was finished most probably in Sidon. It should also be noted that during the Persian period marble sarcophagi were very popular in Sidon: KUKAHN 1955; KLEEMANN 1958; FLEISCHER 1983; SCHMIDTDOUNAS 1985; SEIF 2012.
Chéhab, M.H. 1934. "Sarcophages en plomb du Musée National Libanais," Syria 15.4, 337-350.

Chéhab, M.H. 1935. "Sarcophages en plomb du Musée National Libanais (deuxième article)," Syria 16.1, 51-72.

Chéhab, M.H. 1968. "Sarcophages à reliefs de Tyr," Bulletin du Musée de Beyrouth 21, 1-91.

Clermont-Ganneau, Ch. 1877. "Stèles peintes de Sidon," Gazette archéologique 3, 102-115.

Clermont-Ganneau, Ch. 1888. "Sarcophage de Sidon représentant le mythe de Marsyas," RA 11, 160-167.

Clermont-Ganneau, Ch. 1904. "Archaeological and Epigraphic Notes on Palestine: 25. Platanos and Platanê," Palestine Exploration Fund Quarterly Statement 36, 42-49.

Colonna Ceccaldi, G. 1874. "Nouvelles inscriptions grecques de Chypre," RA 27, 79-95.

Contenau, G. 1920a. "Mission archéologique à Sidon (1914)," Syria 1, 16-55.

Contenau, G. 1920b. "Mission archéologique à Sidon (1914). Deuxième partie," Syria 1, 108-154.

Contenau, G. 1920c. "Mission archéologique à Sidon (1914). Troisième article. La Caverne aux inscriptions," Syria 1, 198-229.

Contenau, G. 1920d. "Mission archéologique à Sidon (1914). Quatrième partie. Les cippes," Syria 1, 287-317.

Contenau, G. 1924. "Deuxième mission archéologique à Sidon (1920)," Syria 5.2, 123-134.

de Jong, L. 2001-2002. "Aspects of Roman Burial Practices in Beirut: on Romanization and Cultural Exchange," Aram 13-14, 293-312.

de Jong, L. 2010. "Performing Death in Tyre: The Life and Afterlife of a Roman Cemetery in the Province of Syria," AJA 114.4, 597-630.

de Saulcy, F. 1853. Voyage autour de la Mer Morte et dans les terres bibliques, Paris.

Domżalski, K., U. Wicenciak, M. El Tayeb, and T. Waliszewski. 2005. "Late Hellenistic and Early Roman Pottery Production Centre at Jiyeh: Rescue Excavations 2004," PAM 16, 429-439.

Dussaud, R. 1927. Topographie historique de la Syrie antique et médiévale (Bibliothèque archéologique et historique 4), Paris.

Duval, N. and J.P. Caillet. 1982. "Khan Khaldé (ou Khaldé III). Les fouilles de Roger Saidah dans les églises, mises en ouvre d'après les documents de l'auteur," in: Archéologie au Levant. Recueil à la mémoire de R. Saidah (Collection de la Maison de l'Orient méditerranéen 12, Série archéologique 9), Lyon, 311-394.

67 FISCHER 1998: 211-212. Cf. WARD-PERKINS 1969: 138139; КОCH 1989a: 209-210.

68 The presence of the same motifs as on sarcophagi can be observed in the relief decoration on Sidonian cippi, hence it is admissible that the same workshops were responsible for carving both classes of monuments. 
El Tayeb, M. 2002. "Archaeological Reconnaissance in Iqlim el Kharoub," in: Waliszewski, Ortali-Tarazi 2002, 10-11.

Fischer, M.L. 1998. Marble Studies. Roman Palestine and the Marble Trade (Xenia 40), Konstanz.

Fleischer, R. 1983. Der Klagefrauensarkophag aus Sidon (Istanbuler Forschungen 34), Tübingen.

Graeve, V. and E. Preusser. 1981. "Zur Technik griechischer Malerei auf Marmor," JdI 96, 120-156.

Gwiazda, M. 2011-2012. "Economy of Hellenistic, Roman and Early Byzantine Settlement in Jiyeh (Porphyreon), Lebanon," Archeologia 62-63, 31-44.

Jakubiak, K. 2011. "Eshmoun Valley Preliminary Report after the Third Season of the Polish-Lebanese Survey," PAM 20, 295-301.

Jakubiak, K. and M. Neska. 2005. "The Eshmoun Valley Survey, 2004. Interim Report,” PAM 16, 441-446.

Jakubiak, K. and M. Neska. 2007. "Eshmoun Valley. Preliminary Report on the Second Season of the Survey, 2005," PAM 17, 431-436.

Jalabert, L. 1904. "Nouvelles stèles peintes de Sidon," $R A 4$, $1-16$.

Jalabert, L. 1906. "Inscriptions grecques et latines de Syrie," Mélanges de la Faculté Orientale 1, 132-188.

Kleemann, I. 1958. Der Satrapensarkophag aus Sidon (Istanbuler Forschungen 20), Berlin.

Koch, G. 1977. "Weitere Fragmente kaiserzeitlicher Sarkophage in Göttingen," $A A, 111-120$.

Koch, G. 1989a. "Der Import kaiserzeitlicher Sarkophage in den römischen Provinzen Syria, Palaestina und Arabia," BJ 189, 161-211.

Koch, G. 1989b. "Sarkophage der römischen Kaiserzeit im Nationalmuseum in Damaskus," DaM 4, 163-179.

Kowatli, I. and H. Curvers. 2006. "A Pottery and Glass Production Site in Beirut," Bulletin d'Archéologie et d'Architecture Libanaises 10, 103-129.

Kukahn, E. 1955. Anthropoide Sarkophage in Beyrouth und die Geschichte dieser sidonischen Sarkophagkunst, Berlin.

Lammens, H. 1898. "Promenade épigraphique a Sidon," RA 33, 109-112.

Lipiński, E. 2004. Itinerari Phoenicia (Studia Phoenicia $18=$ Orientalia Lovaniensia Analecta 127), Leuven - Paris - Dudley.

Macridy, Th. 1904a. "Le temple d'Echmoun à Sidon," Revue Biblique 1, 391-403.

Macridy, Th. 1904b. "A travers les nécropoles sidoniennes," Revue Biblique 1, 547-571.

Masson, O. 1969. "Recherches sur les Phéniciens dans le monde hellénistique," $B C H$ 93.2, 679-700.

Mendel, G. 1912-1914. Catalogue des sculptures grecques, romaines et byzantines, vol. 1-3, Constantinople.

Merriam, A.C. 1887. "Painted Sepulchral Stelai from Alexandria," AJA 3.3/4, 261-268.

Meurdrac, M. and L. Albanèse. 1938. "A travers les nécropoles gréco-romaines de Sidon," Bulletin du Musée de Beyrouth 2, $73-98$.

Meurdrac, M. and L. Albanèse. 1939. "A travers les nécropoles gréco-romaines de Sidon," Bulletin du Musée Beyrouth 3, $37-51$.

Murray, A.S., A.H. Smith, and H.B. Walters. 1900. Excavations in Cyprus, London.

Myres, J.L. and M. Ohnefalsch-Richter. 1899. A Catalogue of the Cyprus Museum, Oxford.

Ortali-Tarazi, R. and B. Stuart. 2002. "Two Rock-Cut Roman Tombs in Chhim," Bulletin d'Archéologie et d'Architecture Libanaises 6, 107-134.

Parks, D.A., M. Aviam, and E.J. Stern. 1997. "Clay Coffins from Agia Napa-Makronisos and their Connections," in: S. Hadji- savvas (ed.), Agia Napa. Excavations at Makronisos and the Archaeology of the Region, Nicosia, 189-196.

Parlasca, K. 1982. Syrische Grabreliefs hellenistischer und römischer Zeit. Fundgruppen und Probleme (Trierer Winckelmannsprogramme 3), Mainz am Rhein.

Perdrizet, P. 1899. "Syriaca II: Le $\pi 0 \lambda i ́ \tau \varepsilon v \mu \alpha$ des cauniens à Sidon," RA III İ̀me série $35,42-48$.

Perdrizet, P. 1904. "Syriaca V: Stéles peintes de Sidon," $R A$ IVème série 3, 234-244.

Perrot, G. 1877. "Inscriptions d'Asie Mineure et de Syrie," $R A$ N.S. XVIII/33, 55-62.

Picard, Ch. 1933. "Le dauphin au trident sur le sarcophage sidonien «au navire»," Syria 14.3, 318-321.

Rahmani, L.Y. 1999. A Catalogue of Roman and Byzantine Lead Coffins from Israel, Jerusalem.

Reinach, S. 1886. "Chronique d'Orient," RA III ${ }^{\text {ème }}$ série 7, 145-170.

Renan, E. 1864. Mission de Phénicie, Paris.

Rey Coquais, J.-P. 1982. "Inscriptions grecques inédites, découvertes par Roger Saidah," in: Archéologie au Levant. Recueil à la mémoire de R. Saidah (Collection de la Maison de l'Orient méditerranéen 12, Série archéologique 9), Lyon, 396-408.

Rey Coquais, J.-P. 2005. "Dix ans d'epigraphie libanaise; inscriptions antiques ou latines," Archaeology \& History in Lebanon 21, 80-89.

Ronzevalle, S. 1910. "Nefes rupestres," Mélanges de l'Université Saint-Joseph. Mélanges de la Faculté Orientale 4, 189-208.

Russell, B. 2011. "The Roman Sarcophagus 'Industry': a Reconsideration," in: J. Elsner and J. Huskinson (eds.), Life, Death and Representation. Some New Work on Roman Sarcophagi (Millenium Studies 29), Berlin-New York, 119-147.

Saade, G. 1976. "Exploration archéologique de Lattaquie," AAS 26, $9-36$.

Sawaya, Z. 2009. Histoire de Bérytos et d'Heliopolis d'après leurs monnaies (I rer siècle av. J.-C. - III ${ }^{e}$ siècle apr. J.-C.) (Bibliothèque archéologique et historique 185), Beyrouth.

Schmidt-Dounas, B. 1985. Der lykische Sarkophag aus Sidon (Istanbuler Forschungen 30), Tübingen.

Seif, A. 2012. "Nouvelle découverte de tombes à Dakrerman," in: E. Cavazzini (ed.), Fascination du Liban. Soixante siècles d'histoire de religions, d'art et d'archéologie, Paris, 79-82.

Seyrig, H. 1953. "Antiquités syriennes 53: Antiquités de la nécropole d'Émèse," Syria 30.1-2, 12-24.

Shapiro, A. 1997. "Petrographic Analysis of Roman Clay Sarcophagi from Northern Israel and Cyprus," "Atiqot 33, $1 *-5 *$.

Stroszeck, J. 1994. "Wannen als Sarkophage," $R M$ 101, 217-240.

Stuart, B. 2001-2002. "Cemeteries in Beirut," Aram 13-14, 87-112.

Tchorek, P. 2002. "Nécropole G," in: Waliszewski, Ortali-Tarazi 2002, 52.

van Ess, M. and L. Petersen. 2003. "Excavation of a Late Roman Necropolis in Baalbek - Douris," Bulletin d'Archéologie et d'Architecture Libanaises 7, 83-107.

Waliszewski, T. and R. Ortali-Tarazi. 2002. "Village romain et byzantin à Chhîm-Marjiyat. Rapport préliminaire (1996-2002)," Bulletin d'Archéologie et d'Architecture Libanaises 6, 5-105. Waliszewski, T., U. Wicenciak, M. El Tayeb, K. Domżalski, A. Witecka, M. Wagner, T. Herbich, I. Noureddine, M. Woźniak, K. Kotlewski, and R. Żukowski. 2006. "Jiyeh (Porphyreon): Hellenistic, Roman and Byzantine settlement on the southern coast of Lebanon. Preliminary report on the 1997 and 2003-2005 seasons," Bulletin d'Archéologie et d'Architecture Libanaises 10, 5-84.

Ward-Perkins, J.B. 1969. "The Imported Sarcophagi of Roman Tyre," Bulletin du Musée de Beyrouth 22, 109-145.

Weber, Th. 1989. Syrisch-römische Sarkophagbeschläge. Orientalische Bronzewerkstätten in römischer Zeit (Damaszener Forschungen 2), Mainz am Rhein. 
Wicenciak, U. 2014. "Pottery Production in the Late Hellenistic and Early Roman Periods at Jiyeh - Ancient Porphyreon (Lebanon)," in: B. Fischer-Genz, Y. Gerber, and H. Hamel (eds.), Roman Pottery in the Near East. Local Production and Regional Trade. Proceedings of the Round Table Held in Berlin 19-20 February 2010 (Roman and Late Antique Mediterranean Pottery 3), Oxford, 103-124.

Wicenciak, U., M. El Tayeb, K. Domżalski, and T. Waliszewski. 2003. "Preliminary Report on a Salvage Campaign at Jiyeh, 2004: The Pottery Production Area," Światowit 5(45)A, 129-134.
Wielgosz, D. 1997. "Funeralia Palmyrena," Studia Palmyreńskie 10, 69-77.

Wielgosz, D. 2004. "Osservazioni sul sarcofago palmireno," in: M. Fano Santi (ed.), Studi di archeologia in onore di Gustavo Traversari (Archaeologica 141), Roma, 929-955.

Yon, J.-B. 2012. "Les cippes funéraires de Sidon et leurs inscriptions," in: E. Cavazzini (ed.), Fascination du Liban. Soixante siècles d'histoire de religions, d'art et d'archéologie, Paris, $117-120$. 